Henry Etzkowitz \& Ashley J. Stevens

\title{
Inching Toward Industrial Policy: The University's Role in Government Initiatives to Assist Small, Innovative Companies in the U.S.
}

\section{Introduction: indirect industrial policy}

The U.S. Government has promoted small innovative technology firms by coupling the funding of basic research at universities, teaching hospitals and research institutes with policies to encourage the use of research results. These policies have favoured small companies and have been accompanied by government initiatives to stimulate the availability of high risk, venture capital investment in new companies. Moreover, improvements in the system of intellectual property protection have reduced the risks of these investments. Government funding of research at companies has been of less importance. Until recently, such direct intervention was confined to technologies considered vital to the military. Indeed, an "indirect policy" to encourage technology transfer from academia to industry was in part created in response to ideological objections to government intervening more directly in civilian industrial innovation.
The Bayh-Dole Act (PL 96-5175), originated in the late 1970's by university officials and legislators to encourage technology transfer, moved the university toward a more central location in the economy. The marketing of $R \& D$, through offices located in the university's central administration, became an overlay on (and, according to some industrially active professors, an interference with) the university's traditional industrial role of supplying trained personnel and basic research knowledge through individual relationships of professors to companies. Technology transfer from academia developed in several stages. Perhaps the most important was the creation of a system of federally supported research in the universities. Government funding though led to the emplacement of barriers between academic research and industrial usage as an unintended consequence of federal policies to insure fair access to a taxpayer supported activity. Policies intended to make 
publicly supported research equally available created a "free rider" effect as companies were unwilling to take the risk of developing such intellectual property, fearing that another firm would lay claim to their work on the grounds that it had, at one time, been supported by tax revenues.

These barriers were inconsequential impediments in an era when U.S. industry maintained world technological leadership through R\&D conducted by firms themselves. In a new era of increased international competition, external sources of R\&D became more important, offering a potential competitive advantage. The build-up of government supported intellectual property in the universities thus became more salient to industry and led to efforts to take down the inadvertant barriers between the spheres. With more direct routes to government intervention in the economy at the micro-level ideologically foreclosed, technology transfer from academia to industry became the industrial policy of choice in the U.S. The development of university technology transfer as an indirect industrial policy, in contrast to more direct approaches taken in Japan and Europe, is our topic in this paper.

\section{The road to technology transfer}

The necessary condition for the creation of technology transfer from universities was the development of an extensive academic research base. The transformation of teaching into research faculties, the "first academic revolution" is still under way in many universities throughout the world. In the U.S., it occurred in the late 19th and early 20th century, giving academic institutions a new mission beyond education and training (Jencks and Riesman, 1968).

Prior to World War II, the government's role in the funding of research at universities had been confined to specialized purposes at a relatively few schools. The Morrill Act of 1862 (United States Statutes at Large, 503-5.) had established the Land Grant
Colleges, whose mandate had been to assist the development of the U.S. agricultural economy and "the mechanic arts" (Hofstadter and Smith, 1962). Today, the Morrill Act is mainly remembered for its impact on agriculture. Some of the funds were turned over to expand existing schools with a practical orientation such as Cornell University while other funds went to start new schools. It is important to remember that the Massachusetts Institute of Technology (MIT) was originally established as a Morrill Act institution, and its experience has been instrumental in the shaping of U.S. policy on the interface between government, academia and industry (Etzkowitz, 1993, 1994b). Indeed, 30\% of the Massacussetts monies were used to help found MIT in 1864.

The Land Grant institutions later became the nexus of the agricultural extension service, which radically transformed the U.S. family farm, the center of the U.S. private sector in the nineteenth century. This policy was extremely effective. Universities became the major crop breeding centers and bred seed lines suitable for the soil and climate conditions of their particular locality. This relationship changed in the 1970's, when changes in intellectual property laws pertaining to crops (the Plant Variety Protection Act and the Plant Variety Certificates that it allowed) resulted in a gradual move of this activity into private seed companies such as Pioneer Hybrid in Des Moines, lowa. Privatization was associated with scientific developments in genetics that potentially universalized plant improvement research, an activity that had formerly been local and regional (Kloppenberg, 1988).

With the notable exception of agriculture and related activities, prior to the Second World War the bulk of academic research funding came from industry and university research was at a much lower level of activity than we see today. For example, the entire research budget of the Columbia University physics department in 1929 was $\$ 10,000$ and that was an exceptionally large figure at the time. In particular, foundations, the philanthropic extensions of corporations, 
played a significant role in encouraging academic research of both a theoretical and practical nature and in creating the project grant system which has become the hallmark of U.S. academia and much imitated worldwide in recent years.

Moving from general grants to support the development of research in broad fields at particular universities, leading foundations, exemplified by the Rockefeller, soon honed in their approach by supporting particular investigators and projects in emerging research fields such as molecular biology (Kohler, 1979). Among the notable projects of this era were the support given to Vannevar Bush to develop the differential analyzer, an early computer, at MIT and to Lawrence at Berkeley for the cyclotron, both in the 1930s. Innovative interdisciplinary collaborations, such as those between MIT mathematician Norbert Wiener and the Mexican cardiologist, Arturo Rosenblueth in the 1940's, were also supported and gave rise to interdisciplinary fields such as mathematical biology.

The Rockefeller Foundation was especially enabled to develop this targeted approach through its development of a staff of professional grants officers who visited universities worldwide, making their own assessment of individual researchers and their research projects. Proposals flowed in to these professionalized staff and were evaluated by them for recommendation for funding. A system of grants for discrete projects was further encouraged by the financial exigencies of the 1930s depression which placed severe limits on the ability of foundations to support the earlier model of broader research support. Much of the current system of basic research support was adumbrated in the actions of the foundations in the early twentieth century. Foundation programs in support of research persist to this date but with the notable exceptions of the Hughes Foundations in the U.S. and the Wellcome Trust in the U.K. in support of medical and biological research, they have become minor players in comparison to support offered by the federal government during the post-war era.

\section{The Second World War}

The next major intervention of the state in R\&D took place at the onset of World War II. The government intervened to improve the technical base of military research by connecting it to the universities. Although the armed forces were satisfied that they could meet their own requirements for technological innovation. However, just before the U.S. entry into World War II academic scientists and engineers who had worked for the military during World War I convinced President Roosevelt that the armed forces needed assistance. Leading academics including the President of Harvard James Conant and Vannever Bush, quondom Vice President and Dean of Engineering at MIT and then Head of the Carnegie Institute of Washington convinced the government that academic science could be used to develop technology for the military. These academics successfully lobbied the executive branch of the federal government to found an agency to support research on military problems. The Office of Scientific Research and Development (OSRD) was placed under the direction of academics rather than government officials or industrialists.

Universities were not the obvious choice for locating such research. With only a few partial exceptions, academic institutions lacked large research centers with the ability to carry on research and development. Industrial research laboratories at major corporations had greater R\&D capabilities that could potentially be quickly turned to military use. But industrial scientists and engineers had not taken the lead in approaching the government. Industrial scientists such as Frank Jewett, the head of Bell Laboratories took part, but in a secondary role supporting the lead taken by academics such as Bush and Conant. Since the research leaders who took the lead in this initiative were from the universities, they were placed in control of the agency established to carry out their plan and thus had the responsibility to dispense the funds allocated for the task. 
Academics had to be drawn together from campuses across the country to establish large scale research centers at a relatively few universities: MIT, Johns Hopkins, Berkeley, Chicago and Columbia. The so called Rad-Lab at MIT and a few other laboratories were established in electronics, nuclear physics and other scientific and engineering areas relevant to solving military problems. This resulted in a concentration of research in a few institutions, against the ideology both of government and of universities. The American academic system is highly decentralized with a multiplicity of institutions competing for funds of all kinds. Under conditions of military necessity, a few academic leaders were able to persuade their fellow academics to accept a concentrated system. Academics also agreed to accept federal research funds that they had refused during the 1930s depression, fearing that research direction might be affected. An overriding purpose, the exigencies of war, changed academics' actions and then their beliefs.

\section{The emergence of contradictions between academic research and its industrial use in the post-war era}

The successful R\&D effort coordinated by the Office of Scientific Research and Development (OSRD), largely on a few university campuses, suggested to Bush that the Federal Government could promote the development of new technologies by funding basic research. A vigorous debate ensued as to whether this research should be done in the context of national laboratories, as had been done in the wartime effort, or of universities, that were also involved in war time research. The question was whether civilian research should be located in the universities and military research in government laboratories or was it more efficacious to keep university scientists, many of whom were determined to leave the wartime labs immediately after the close of hostilities, involved in defense research from their academic bases.

Also at issue were the boundaries between military and civilian research and the question of where the locus of control should be placed (Owen, 1994). Much of this controversy was played out in the debate over the control of atomic research which was eventually placed apart from the military in a new civilian agency, the Atomic Energy Commission, but under strict security controls. The closure of the war-time OSRD had given rise to separate research agencies in each military service who were now convinced, after the wartime experience, of the efficacy of the contribution of basic research to military goals and wished to maintain ties to the civilian basic research establishment, much of it located in the universities (Etzkowitz, 1994c).

In the interim, while the issues of how to organize government support of research were debated, a military agency, the Office of Naval Research (ONR), stepped into the breach and offered support for basic research, albeit with long-term military implications expected. The outcome was a compromise. The National Laboratories were funded directly and focused on defense related work, while the National Institutes of Health, tracing their origins to the midnineteenth century, were given the mission of health research.

In parallel with the expansion of research activity within government, the peer review system of federal funding of research at universities was established. The key element of this approach is that ideas for research are developed by scientists and the validity of these ideas is determined by committees of other scientists who work in the field. The separation of science from politics was made compatible with the expectation of government that research was useful through a peer review system, largely turning disbursement decisions over to academics within the confines of grant programs. Just after the war, the National Institutes of Health, in addition to being expanded from a small intramural research 
institute, was also given the mandate to manage extramural research in the medically related biological sciences. The National Science Foundation was established in 1950 to fund the physical sciences, the nonmedical biological sciences, and soon thereafter, the social sciences and engineering.

Outside of defense needs, more basic research has been funded at universities than at National Laboratories. Medical research was also supported to meet military needs during World War II but the major impetus to the development of medical and biological research at universities in the past several decades has come from social movements and lobbying groups directed toward the cure of diseases. The health social movements to cure diseases, from cancer to heart to Alzheimers, support voluntary associations that fund research. These associations typically feel they are not able to raise sufficient funds to accomplish their goal and thus exert political pressure to expand the federal role in health research. As a result the National Institutes of Health grew through the efforts of social movements interested in using research to solve health problems. Most of the diseases that the NIH was funded to cure are still with us but the U.S. has a biotechnology industry as an unintended side effect of the generous support of basic research.

\section{Management of intellectual property generated under federal funding}

Bush was aware from his interwar experience at MIT that an expansion of research would generate intellectual property and that patentable research would have to be managed if conflicts were to be avoided and rewards from research returned, at least in part, to their originators. Otherwise, emoluments would go to opportunists who viewed the university as a site of research results to freely draw upon and patent as their own. This was the view from MIT and it led to the formation of committees to develop an academic patent policy at the Institute as early as the 1920s (Etzkowitz, 1994b). Naturally, when OSRD was established there were provisions made for the patenting of research (Purcell, 1979). Even during war there was a view toward peace when, with the lifting of wartime constraints, arguments would likely ensue over property rights in research if precautions were not taken. One of the prices that was paid for the provision of federal funding of research was strict controls over the use to which the results of the research could be put. The basic philosophy was that no company should be able to generate large profits at the expense of the public by the exploitation of patents that had been publicly funded by the taxpayer.

The result was that, during the early postwar era, only non-exclusive licenses could be obtained to exploit the results of academic research. The thought was that by licensing more than one company to practise a given invention, competitive forces would keep prices "reasonable". Licensing was centrally managed by an organization called the National Technical and Information Service (NTIS), located in the Department of Commerce, with traditional responsibilities to conduct scientific research in support of precise weights, measures etc., renamed, expanded and given new responsibilities for support of industry. This approach was reasonably effective in managing patents in fields in which product development times were reasonably short and hence the development risk that a company took on was not excessive, in such fields as mechanical devices, electronics, chemical processes. However, the approach completely broke down in areas with long development timeframes such as the pharmaceutical industry.

In 1968, the Johnson administration conducted a study which found that no pharmaceutical to which the Government owned the patent had ever been developed for commercial use. Companies were simply not prepared to make the investment required to develop a drug, a cost that could 
run into many millions of dollars (even then, before the passage of the Food, Drug and Cosmetic Act of 1973 raised the cost of obtaining marketing approval for a new drug substantially), without the guarantee that they would be able to recoup their investment through exclusive marketing rights.

The first response to the Johnson Administration's study was the development of Institutional Patent Management Agreements (IPA's). These were first implemented by the Department of Health, Education and Welfare (HEW) and later by the National Science Foundation. They allowed institutions to negotiate title rights to inventions made with federal funding. The process was long and arduous, typically taking three years. An institution starting down this road in response to a specific invention would probably have found the potential licensee's interest had lapsed by the time the agreement was in place. There were restrictions on the period of exclusivity under IPA's, to ten years. However, they provided a valuable precedent for the ability of academic institutions to successfully and responsibly manage their technologies.

Industry's view of academia as a source of intellectual property at this time were exemplified in a 1980 survey (National Science Board, 1982) in which 56 firms were asked why they funded research at universities. Multiple answers were possible. The reasons cited were as follows:

Table 1: Reasons Cited for Sponsoring Academic Research in 1980

\begin{tabular}{ll}
\hline Gain access to manpower & $75 \%$ \\
Window on science and technology & $52 \%$ \\
General support of technical excellence & $38 \%$ \\
Gain access to university facilities & $36 \%$ \\
Obtain prestige; enhance company's image & $32 \%$ \\
Good local citizen; foster community relations & $29 \%$ \\
Make use of an economical resource & $14 \%$ \\
Solve problem; get specific information & \\
$\quad$ unavailable elsewhere & $11 \%$ \\
\hline
\end{tabular}

The last of the reasons cited is a good working definition of a proprietary advantage; in 1980 it was the last reason that companies looked to universities.

\section{Legitimizing academic technology transfer: the Bayh-Dole act}

Officials from a few academic institutions, typically with a "land grant" tradition and/or extensive capabilities in bio-medical research with commercial implications, took the lead in getting legislation passed to establish a new framework for technology transfer. These efforts took place in the context of increasing international competition for U.S. companies and the failure of the Carter administration's "reindustrialization" proposals to directly assist companies. Thus, there was a receptive atmosphere for ideas to assist industry indirectly with the results of government supported research.

In 1978, Purdue University wanted to negotiate an IPA in order to commercialize promising medical device technology but was told that the Department of Health, Education and Welfare (HEW) had stopped granting such Agreements (Personal communication from Howard Bremer, Wisconsin Alumni Research Foundation to Ashley Stevens). They approached their Senator, Birch Bayh, to protest what appeared to be an arbitrary decision, and found a sympathetic ear. Bayh found that the Department of Commerce was starting to have concerns about the U.S.'s international competitiveness and felt that the barriers that had developed between academic and industrial R\&D were contributing to the problem. In turn, Purdue found support for a change in the current system from other leading universities such as: 1) Wisconsin whose discovery of vitamin $\mathrm{D}$ and warfarin had put them at the forefront of developing the academic technology transfer paradigm, starting in the early 1930's; and 2) Stanford whose origins in industrial research mirrored those of MIT an, at the time, was preparing to found the biotechnology industry through the CohenBoyer patents on recombinant DNA technology.

Bayh, a Democrat, found a bipartisan cosponsor in Republican Robert Dole, and in 1979 serious consideration started of the 
Bayh-Dole Bill. The Bill came under the jurisdiction of the Senate Judiciary Committee, chaired at the time by Senator Edward Kennedy of Massachusetts. The enormous importance of higher education to the economy of Massachusetts insured a sympathetic hearing for the Bill. The Senate Judiciary Committee found that in 1978, the Government owned title to over 28,000 patents, and had licensed fewer than $4 \%$ of them, glaring evidence of the lack of success of the then current approach. In addition to the restrictions on license terms, other factors responsible for the lack of success were the bureaucratic difficulties of working with a government agency and the separation of the inventor from the invention.

Academic technology is so embryonic that the active involvement of the inventor is usually essential to its further development. With the University controlling access to the inventor, but NTIS controlling the licensing rights, there was a fundamental disconnect between the two required elements.

The Bayh-Dole Act (PL 96-517) formally known as the Patent And Trademark Amendments Act, was passed. It applied to not-for-profit institutions and small businesses (defined as those with fewer than 500 employees). It contained six important provisions:

1. Universities could elect to retain title to the results of federally funded research

2. Universities were required to share proceeds with inventors

This was the most important aspect of the Act. The concept of patenting was foreign to most academics. Their academic reputations, under conditions then current, would not be enhanced by adding patents and licenses to their curriculum vitaes. In contrast to corporate R\&D scientists who typically are required to sign away their patent rights as a condition of employment, academic scientists and engineers were given a tangible incentive to expand their purview to include the commercialization of research. U.S. academics joined German workers as beneficiaries by law in the fruits of their creativity.
3. Restrictions on licensing terms were removed

Licenses to small businesses could be for the lifetime of the patent. Licenses to large businesses were still limited to ten years.

\section{U.S. manufacture required for products} to be sold in the U.S.

This requirement was to ensure that a reasonable share of the benefits flowed into the U.S. economy. Waivers can be obtained if the licensor can show the agency that funded the research that the licensee cannot economically develop the product if this requirement is enforced.

\section{Small business preference}

This was one of the most debated aspects of the Act. There remained considerable concern in the Senate about handing monopoly power that had been created with Government funding to large corporations. It was felt that small companies would be less able to exploit that monopoly power at the expense of the public than would large companies, so a preference for small companies was incorporated into the Act. The meaning of the requirement has never been seriously tested. If an institution received equal offers to license a technology from a large and a small company, then clearly it would have to accept the small company offer. However, this is never the case. Licensing proposals always differ, so the overall economic attractiveness of the competing offers must be compared and weighed.

Also, in practice, small companies have found themselves best able to work with academic institutions and have emerged as the main licensees of academic technologies. Congress appears comfortable with looking at the results of university licensing in total, not on a case by case basis and interpretation of this issue has therefore never been rigorously challenged.

6. The Government retained a nonexclusive license to use the technology and march-in rights. 
The Government's license is for its own use only. This therefore primarily impacts technologies for which the Government is the primary consumer and has not been a major factor. The march-in rights give the Government the right to take back title if it believes that an important technology is not being properly exploited. The authors are aware of at least one instance where this has happened, but it is certainly not a widespread practice and has not been an important factor in technology commercialization.

Another of the issues that was intensively debated at the time was whether the Government should receive a share of the results of licensing the technology it had funded. The Senate Judiciary Committee decided that the Government's return would come not directly from a share in the proceeds, but rather from the increased taxation that would result from the increased economic activity that would be a consequence of the Acts' successful implementation. The federal legislation assigned ownership of knowledge to the university in which the discovery was made, if the research had been supported financially by the federal government. The purpose of the new federal legislation was to speed the transfer of technological knowledge from university to private industrial firms by eliminating governmental restrictions on the private use of the results of governmentally supported research. It was left to academic institutions to decide how to accomplish this goal.

\section{Operationalizing technology transfer as a university mission}

Universities that were previously little involved in the transfer of technology quickly established administrative offices in the wake of the federal decision. Universities with some experience either on their own or through arrangements with the Research Corporation soon expanded their efforts to take out patents on the commercialisable research of their academic staff. By the late 1980's virtually all research universities had established a technology transfer office. Following upon the growth of these offices, a membership organization, the Association of University Technology Managers (AUTM) was established to represent the emerging profession. AUTM membership has since risen to 600 full and 600 associate members and the organisation runs its own training programs.

All major, and many minor, academic institutions, as well as an increasing number of government laboratories in the U.S., now have technology transfer offices. Some, such as the National Institutes of Health, Stanford, MIT and the University of California system have offices of 30-50 people. A smaller, less research oriented medical school, New York Medical College, has a staff of a single person. Awaiting a buildup of research with commercial potential, the Westchester based medical school is at the stage of developing its policy documents and seeking partners in the pharmaceutical industry to become a site for clinical trials.

There are two essential elements to academic technology transfer: 1) the ability to license established technologies for which patents have been applied; and 2) the ability to collaborate with the inventor of the technology to further develop it.

While the first of these two steps in fact constitutes the actual transfer of the technology, because of the very early stage of academic technology, it is not worthwhile doing so unless the second option is also available and the co-operation of the inventor achieved.

Some universities extended their efforts from the taking out and licensing of patents to produce income for the university into a portfolio of measures designed to establish new firms and thereby promote regional economic development. All of these efforts depended upon research staff and students bringing their commercialisable ideas to the attention of a university technology transfer office. In part because the taking out of patents was expensive, patents were often only sought when a prospective licensee 
could be identified. Universities had the reputation of being conservative patent takers. There was either an immediate sale or a long term prospect of significant gain, with little middle ground.

The issue of the disposition of the returns from intellectual property rights derived form government supported research continually reappears within and without the universities. The most contentions internal issue within the universities appears to have been settled with a, more or less, equal three way division of proceeds among the university administration on behalf of the institution as a whole, the faculty members department and the individual themselves. Student generated rights were traditionally left entirely with the individual, perhaps on the grounds that they paid tuition and didn't have employee status. However, since most graduate students in the sciences are on fellowships, often from a government or university source, they have increasingly been defined as "officers of the university" subject to the same intellectual property rules as faculty.

A below the surface issue that rarely comes to light given faculty members near feudal power over their students in assessing progress toward the Ph.D. and in granting degrees is claims made by faculty members to credit, both intellectual and pecuniary, of graduate student research. The academic system has virtually accepted a system of authorship by status in which provision of resources to conduct research caries with in an entitlement to credit of all kinds. As intellectual property rights become more salient it can be expected that relations among teachers and students will have to be more clearly defined. In U.S. academia such redefinition of roles typically takes place in the context of "conflict of interest and commitment" disputes over the propriety of individual actions when pecuniary selfinterest or competing responsibilities are involved. A series of such disputes in the 1980 s led to the clarification of the relationship between faculty and administration in the context of an overall redefinition of the mission of the university as one that encompassed economic development as well as teaching and research.

Etzkowitz has called this change "the second academic revolution" following upon the first academic revolution of the late nineteenth and early twentieth century in which research became an accepted academic mission, along with teaching, after resolution of a series of conflict of interest disputes, over the proper balance between these two activities during that earlier era. Indeed tension still persists over the issue of whether too much attention has been given to research at the expense of teaching and calls for redressing the relative emphasis periodically occur. There is also a wide range of compromises among these different activities of teaching, research and economic development in the 3,500 institutions that comprise the U.S. tertiary education system. It can be predicted that economic development as an academic mission will follow a similar course as the tension ridden relationship between the two older missions, even as it becomes embedded as a taken for granted part of the academic structure (Etzkowitz, 1990).

The actions taken in response to the passage of the Bayh-Dole Act produced, over the next decade, a profound attitudinal shift in U.S. universities on the role of academic research and the contribution it can make to economic development. Other countries are only just beginning to attempt to emulate this role in their own universities, for example, by introducing centers into the academic structure in Sweden and science parks in Finland (Etzkowitz, 1995). Academic scientists in the U.S. are entrepreneurs. Under the peer review system, they must raise the funding for their research activities themselves. A large research division at a university or teaching hospital can therefore be regarded as a quasi-business with revenues of from $\$ 1$ million to $\$ 10$ million in annual revenues. The Bayh-Dole Act allowed these natural entrepreneurs to apply their talents to the benefit of the for-profit sector. 


\section{The extension of academic technology transfer models to government laboratories}

In the Stevenson Wydler Act, (PL 98-620) passed in 1984, Congress mandated the national laboratories to play a technology transfer and cooperative research role with industry. Laboratories typically had one customer, a particular department of the government, for example, Los Alamos in nuclear weapons research for the Department of Energy or Livermore, to do similar kinds of nuclear and Star Wars research. National laboratories were instructed that, in addition to what you normally do, if things come up in the course of your research that would be useful to civilian industry, some of your engineers and scientists should transfer that work to industry.

The Stevenson-Wydler Act extended Bayh-Dole (e.g. to include the results of research conducted at Government owned, contractor operated National Laboratories, such as MIT's Lincoln Labs) and removed many of its remaining restrictions (e.g. on the length of exclusivity of licenses that could be issued) to further make explicit the technology transfer responsibilities associated with all government research funding. Thus, the national laboratories soon began to establish technology transfer offices, often modelled on those existing in the universities, and to conduct joint research with companies through Cooperative Research and Development Agreements (CRADA's).

The National Laboratories had always had the same right to apply for patents on the results of their research as had the universities. The licensing of the patents was traditionally handled by the National Technical Information Service (NTIS). This organization operated under the philosophical perspective described under the earlier discussion of academic licensing, that companies should not be able to gain a competitive advantage from government funded technology. There was therefore a requirement that any exclusive license of technology contemplated by NTIS first be advertised in the Federal Register. Companies that thought they might be harmed by such a transaction then had sixty days to register their concern and either compete for the license or persuade NTIS to grant non-exclusive licenses instead. This made licensing a technology from NTIS a more daunting process than licensing from an academic institution in the post-Bayh-Dole era.

However, even if a company successfully negotiated this hurdle, there was still no way for it to interact with the inventor to further develop the technology if the inventor worked at a National Laboratory. This imposed a further handicap on federal scientists. The Federal Technology Transfer Act (PL 99502) was therefore passed in 1986 in response to the success that was almost immediately seen from the Bayh-Dole Act. It was intended to allow scientists at government owned, government operated ("GOGO") National Laboratories to interact with industry in an analogous manner to that in which universities, teaching hospitals and independent research institutions are able to under the Bayh-Dole Act. In 1989, as part of the National Competitiveness Act (PL 101189), authority for these collaborations was extended to government owned contractor operated ("GOCO") labs.

Its most visible effect has been the establishment of Co-operative Research and Development Agreements (CRADA's). Less visible but perhaps even more significant, in the long term, was the emergence of a commitment to transfer technology at the laboratory level. Each Department has set up its own technology transfer office; NIH's has 45 employees, making it as large as the largest academic office of technology transfer, that of the University of California's office and each laboratory has set up technology liaison officers to act as a focus for its own technologies. An association to represent these professionals, the Association of Federal Technology Executives (AFTE) was founded in 1993, 
modelled on the Association of University Technology Managers.

CRADA's have become a well-established feature of the technology transfer scene. To develop a CRADA, the laboratory and the company jointly develop a research program. One of the important considerations is that the company must contribute to the scientific program. This is in contrast to many typical university sponsored research agreements, in which the company's role may be limited to providing funding and no scientific help. As a trade off for this contribution, the laboratory is not required to seek the full cost of the research from the collaborator. Indeed, the laboratory is not allowed to apply corporate funding to support its base operations. Corporate funding may only be used to expand operations; to add additional post-doctoral fellows or technicians to work specifically on the project. This may have led to some abuses, with companies that were planning to work in an area anyway offering up their efforts as their contribution to a CRADA. In addition to the benefits of the technology developed, a major benefit of entering a CRADA is that the company can exclusively license the results of the CRADA without the Government's intention of granting an exclusive license being advertised in the Federal Register in order to solicit competing bids for the technology.

\section{Second thoughts: the critique of academic technology transfer}

What is the future of academia as the traditional basis for research support, if the so-called contract between university and government, weakens? (Guston and Kenniston, 1994) The diminution of federal research support could also affect the ability of the universities to carry out technology transfer. But are the universities ready to accept contribution to economic and social development through technology transfer as an explicit mission and justify receipt of public resources on this basis, directly rather than as an afterthought?
Some universities, those close to the MIT/ Stanford and "land grant" models have eagerly taken up the challenge of regional economic development. For example, in 1985, the state legislature asked lowa State University to review its management contract of a federal laboratory, suspecting that the university (and the state) was losing more than it was gaining from the relationship. The university found, on the positive side, that the laboratory was supporting the research infrastructure of several departments including physics, chemistry and engineering. On the other hand, the intellectual property emanating from the laboratory was primarily being licensed abroad rather than contributing to local economic development. The university began the process of founding start-up firms to develop research locally, successfully creating jobs and economic activity in lowa from the intellectual property of the university and the federal laboratory during the past decade (Personal communication from Michael Crow, Columbia University, Nov. 29, 1995).

At other universities, as the technology transfer profession generates ever more glowing reports of its ability to generate returns from federally sponsored research, skeptics contend that academic attention to technology transfer is misplaced on the grounds of wasted effort that will not produce significant results. To this day, there is a division of opinion among university faculty, especially at elite universities oriented to the liberal arts and basic research, over whether patenting or indeed any attention to the commercial implications of research is appropriate. Indeed, it was at these same universities that government funding of research was severely questioned and ultimately rejected during the 1930s. At Columbia University, as late as 1952, a faculty member in biochemistry in the Medical School viewed government research funds as "tainted" (Personal communication from Seymour Lieberman, Nov. 29, 1995).

Since that era, government funding of research has become academic orthodoxy. 
Ironically, as it is currently under threat of reduction; that diminution is viewed as an attack upon academia. In the face of this decline, a parallel system of generating funds from academic research through technology transfer has been created. Nevertheless, this system is still in its infancy and many question whether it can ever become a significant source of resources for academic research let alone a serious input into the economy. In addition, some critics hold that technology transfer detracts from academia by deforming the university from its traditional missions of research and education, their unique function (Feller, 1990).

Others argue that moving more closely to industrial research interests smacks of "short termism" and will be duplicative of industrial research laboratories. A focus on technology transfer makes the university into a barrier between university and industry. It displaces the free flow of knowledge, through publication and informal discussion, with a wasteful effort to capitalize knowledge and reap a return for the university. "Technology transfer efforts which focus on industrial development of PSR [public sector research i.e. university and government laboratories] 'inventions' are misplaced and out of proportion; by far the greater contribution of PSR to innovation lies in the less direct and intangible flows of ideas, knowledge and expert assistance." (Faulkner and Senker, 1995)

Questions of whether the university should engage in technology transfer are confounded by calls for redistribution of these publicly originated benefits. For example, in the 1993 hearings held by the U.S. House of Representatives Small Business Committee Representative Ron Wyden, the Chair of the Committee, called for some of the profits from "taxol", a pharmaceutical derived from tree bark, to be returned to the public in the form of lower drug prices. There was also a proposal made at the Cold Spring Harbor conference held later in the year to discuss the controversial relationship between the Sandoz Company and Scripps Institute that some of the profits from university technology transfer be directed to a "trust fund" to support NIH and NSF research. Such a proposal would replicate, on a more massive scale and in a public format, the model of the Research Corporation, discussed above. Naturally, individual universities, especially those that are generators of significant royalties prefer to keep the profits in-house and make their own research investment decisions rather than turn them over to these redistribution schemes.

As we have seen, there is an additional issue related to the question of whether the university should sell its intellectual property to the highest bidder. Although the official injunction to favour small firms has no enforcement mechanism there are pressures on universities from local authorities, especially those that have subsidized universities to develop technology transfer capabilities, to see that the intellectual property rights that they generate are developed locally. This can take the form of licensing to a local start up with little or no royalties in the short term as opposed to selling the rights, often to a larger firm elsewhere, with an immediate return. This issue is often played out in cross-pressures of a university president pressed to seek maximum returns in an era of academic financial stringency and a local government agency seeking to create jobs in the region, with the university technology transfer office having to balance between these two masters.

Earning money from technology transfer has to be balanced against competing academic goals as well as the regional interest in using the university's research results to establish new firms locally rather than marketing intellectual property to the highest bidder among established companies elsewhere. A policy of licensing technology to local startups, promoted by the provisions of the Bayh-Dole Act also creates an incipient conflict between universities and large corporations over technology transfer. While some technology licenses go to large companies; new competitors are also 
created. The University-Industry Government Roundtable in the U.S., strongly representing major corporations, has called upon universities to encourage the free flow of knowledge from academia to industry, intending "free flow" to mean both "without impediment" and "without cost."

\section{Measuring the economic impact of technology transfer}

The establishment of technology transfer offices and the array of mechanisms, including incubator facilities and science parks, gives hope (some say, false hope) to regions that have not yet seen a glimmer of a high tech valley, coast or corridor. In the face of injunctions to give up the protection and marketing of intellectual property AUTM has attempted to justify the contribution of university originated technologies to the U.S. economy and, by implication, the utility of the technology transfer profession. These reports justify the expense that universities have undertaken in subsidizing technology transfer offices, patiently waiting out the seven lean years that are not expected to pay for themselves. We shall view, in turn, the results of the Research Corporation, government laboratories and universities. ${ }^{1}$

University technology transfer offices have, in recent years, internalized a task performed for some years by an organization founded for that purpose, The Research Corporation, now Research Corporation Technologies (RCT). During the pre-war era, even MIT had this intermediary organization, independent of the university, market its intellectual property not wanting the university to be too closely identified in the public mind with pecuniary interests. In the 1960s MIT took full control of its patent management activities when its interests diverged from RCT in a dispute with IBM over corememory. RCT wished to fight in court for the maximum amount; MIT had other interests to consider. Since IBM was an important philanthropic donor and sometime joint developer of Institute technologies it was more important to maintain good relations with the company than to extract the maximum royalty. (Etzkowitz, 1994b).

RCT is the longest established technology transfer organization serving academic institutions, having been founded in 1917 by Frederick Cottrell, a professor of physical chemistry at the University of California, who had invented the electrostatic precipitator technology to solve emission problems from coppersmelters in the San Francisco Bay Area. For several decades RCT, with a few exception such as the Wisconsin Alumni Foundation, had the academic technology transfer field to itself, visiting campuses to identify inventions and distributing its earnings in the form of small research grants to faculty members.

RCT operates by taking title to inventions and marketing them at its own expense, in return for a significant share in the proceeds, typically in the $40-50 \%$ range and distributing the balance to the originating institution. One of its most successful transactions in recent years has been the licensing of Michigan State's platinum chemotherapy compounds to Bristol-Myers Squibb. As part of the 1986 tax reform act, RCT transferred its invention identification and development activities to a taxable nonprofit corporation set up by the original foundation, which remained as a grant giving agency?

RCT's results since the 1987 reorganization are as follows:

Table 2: RCT Royalty Receipts and Disbursements (\$000's)

\begin{tabular}{lrrr}
\hline & 1987 & 1990 & 1993 \\
\hline Total & 13,478 & 32,273 & 57,664 \\
Retained & 9,295 & 21,259 & 36,085 \\
Distributed & 4,183 & 11,014 & 21,579 \\
\hline
\end{tabular}

\section{Federal laboratories}

The role of national laboratories in technology transfer has increased greatly, with the end of the Cold War, as some government laboratories have entirely lost their previous mission. In order to stay in existence, they are eagerly taking up the 
tasks of technology transfer and providing research services to industry as one of their main missions. Until recently, it was assumed that most of the money that the federal government gave to national laboratories and universities for research, with the exception of basic research, health and agriculture, was tied to military purposes. Now that these purposes have lessened or even disappeared, uses for those funds for new purposes must be found or we can expect the research universities and the national laboratories to shrink greatly, reflecting the extent that their research activities were tied to defense related projects that are no longer needed. Should technology transfer be successfully implanted as the primary, rather than as merely a subsidiary, mission of a significant number of national laboratories, the U.S. would gain the virtual equivalent of the German Fraunhaufer system of industrial support laboratories.

The GOO study "Technology Transfer: Federal Agencies' Patent Licensing Activities" (GAO/RECD-91-80; April 1991) prepared for the House and Senate Judiciary Committees and the House Committee on Science, Space and Technology, gave a ten year summary for 1981-1990.

Table 3: Federal Laboratory Royalty Income (\$000's)

\begin{tabular}{lr}
\hline 1981 & 346 \\
1986 & 1,642 \\
1990 & 9,389 \\
1993 & 18,000 \\
\hline
\end{tabular}

The following figures estimate total royalty receipts from Public Sector Research (PSR) consisting of U.S. academic institutions and government laboratories:

Table 4: Adjusted Total PSA Technology Transfer Royalty Income

\begin{tabular}{lc}
\hline Year & \$ millions \\
\hline 1980 & 7.3 \\
1986 & 38.1 \\
1990 & 136.5 \\
1993 & 344.4 \\
\hline
\end{tabular}

The 1993 earnings of 344 million represent a small $(8.6 \%)$, but increasingly significant amount, in comparison to the 4 billion dollars of federal expenditures for basic research at U.S. universities per annum (Office of Technology Assessment, 1991: 188) ${ }^{4}$. As table 5 bellow suggests, most of the funds earned by universities, thus far, derive from a fairly narrow research stream of biotechnology related pharmaceuticals. Some critics take this to mean that technology transfer is largely confined to a single sector of the university and will remain a minor factor in academia. Proponents argue the contrary, that this same table represents only a beginning and that significant software patents and multi-media companies will appear, not only from computer science and engineering but even from the arts and humanities departments of the university.

Table 5: Academic Institutions with Largest Royalty Income and Licensee Thereof

\begin{tabular}{lccc}
\hline Institution & Royalty Income & Major Licenses & Licensees \\
\hline City of Hope & 18 & Insulin, hGH & Genentech \\
Stanford & 14 & Cohen-Boyer & Biotech, Pharm \\
U. California & 12 & Patch,Cohen-Boyer & Biotech, Pharm \\
Wisconsin & 12 & Warfarin, Vit. D & Pharm \\
New York Blood Center & 8 & Viral decont. & Various \\
Columbia & 7 & Co-transformation & Amgen \\
Michigan State & 7 & cis-platin & Bristol-Myers \\
MIT & 4 & Miscellaneous & Small \\
Sloan-Kettering & 4 & G-CSF & Amgen \\
U. Florida & 3 & Gatorade (trademark) & Coca-Cola \\
\hline
\end{tabular}




\section{Economic impact}

These data on royalty income can be used to provide a very crude estimate of the economic impact of PSR technology transfer activity. Based upon the average royalty rate paid to the universities and government laboratories of $\$ 344.4$ million in royalties at a $2 \%$ average royalty, the total sales of the licensed products can be estimated to be $\$ 17.2$ billion $^{5}$. Product sales can also be used to estimate the employment generated by technology transfer to consist of 137,800 jobs created. ${ }^{6}$ The economic impact of technology transfer from universities and government laboratories has evolved since the passage of Bayh-Dole and StevensonWydler to a point where it can be considered to be playing a recognizable and increasingly significant role in aiding the growth of the U.S. economy.

Table 6: Estimated Economic Impact of PSR Technology (\$ million)

\begin{tabular}{lrrrr}
\hline & 1980 & 1986 & 1990 & 1993 \\
\hline Product Sales & 365 & 1,905 & 6,825 & 17,220 \\
Employment & 2,920 & 15,240 & 54,600 & 137,760 \\
\hline
\end{tabular}

The drafters of the Bayh-Dole Act realised their legislative intent to attain public benefit from university technology transfer through contribution to tax revenues. The economic activity arising from tech transfer shows a return to federal and state governments of approximately $\$ 3.9$ billion in 1993. It is also worth noting that these estimates are undoubtedly low, for two reasons:

1. Once patents expire, royalties cease, but the products remain in the market. For instance, in the mid 1960s, MIT had licensed two very important technologies, synthetic penicillin and computer core memory. Both patents have now expired, but were the foundation of major markets.

2. This methodology doesn't capture the induced investment effect, when technologies are in development and are employing people but not yet generating revenues. Thus, the above figures are conservative estimates of the economic impact of indirect industrial policy.

\section{Conclusion: inching toward industrial policy}

In the U.S. government intervention in the civilian economy did not take place directly as it did in France. Nevertheless, emerging companies funded by the Department of Defense (DOD) Advanced Research Projects Agency (ARPA) such as SUN Microsystems and Silicon Graphics, created a new category of computer "workstations" with significant spillover to the civilian economy. These companies, achieving ten billion dollars of sales within a decade, did not sprout from Stanford University unaided, (the SUN acronym stands for Stanford University System). The DOD acted as venture capitalist to the workstation industry in the 1980 s even as it had served the same function in the 1960s for the mini-computer and military electronics industries on Route 128. These defense related exceptions apart, government intervention in commercialization of civilian technology had been largely discredited in the energy crisis of the 1970s when government funded company efforts to commercialize shale oil did not achieve results quickly.

Such examples gave rise to a rhetoric touting the inability of government to "pick winners" and appeared to justify the confinement of government to the role of funding basic research during the Reagan/ Bush administrations on the accepted grounds of the inability of the market to undertake such a task. Full wisdom was imputed to the market to select technologies despite the prescient efforts of DARPA. Another significant exception to prevailing ideology, arising from industry pressure, was the DOD funding of the SEMATECH cooperative research scheme to revive the technology of the semi-conductor industry then believed to be in severe danger of loss to competition from Japan. Despite taking ideological exception, the Reagan 
administration committed the necessary funds at the behest of the Semi-Conductor Industry Association in the mid-1980s. Less than a decade later, the industry declared both the utility of the effort in regaining competitive superiority and the lack of need for further government funds to maintain the cooperative pre-competitive research scheme. Current opposition in Congress to renewing the funding of the Advanced Technology Program (ATP), part-funding the development of generic technologies, mostly by large companies, is another expression of such ideological opposition to industrial policy.

Despite such opposition, the U.S. has taken range of initiatives at the federal and state levels, during the post-war era, to facilitate knowledge-based economic development. Taken together they comprise an incipient industrial policy. In this article we have focused on one aspect of these initiatives; the effects of the adjustment of patent policy at the federal level. Changes in patent policy have induced a reordering of relationships among the knowledge sector, the economy and the state. The Carter administration was unable to establish an explicit industrial policy during the late 1970 s in the face of laissez faire objections. Instead, universities were encouraged to act as a surrogate for government through incentives offered to induce schools to become technology transfer agents and commercialize research.

The Bayh-Dole Act altered the regulatory infrastructure which determined how the results of research which would have been funded any way could be utilized. No funds were appropriated for its implementation or administration. By changing the rules of the game, placing responsibility for technology transfer in the university where it was being conducted rather than with government, the funder, potentially useful research was moved closer to users. In the context of federal research budgets that were not growing at a fast enough rate to meet academic researchers' needs, universities were given the opportunity to earn monies from the royalties and equity that they could generate from federally sponsored research on their campuses.

The Morill Act of 1862 donated federal land to support the development of higher education for the improvement of agricultural and industrial practice. The laws of 1980 turned over intangible property of scientific and technological knowledge to the universities with similar intentions. A few universities were already oriented toward technology transfer; others soon turned in this direction. The legislation led universities to experiment with a variety of arrangements to develop fruitful relations with industry such as research parks, incubator facilities and offices for the transfer of technology and, by stimulating the universities to undertake these initiatives, encouraged interested academics to include commercial activities in their roles.

The purpose of the federal legislation was to speed up the transfer of scientific technological knowledge from university to private industrial firms. It was to be left to the academic institutions to make their own arrangements for the commercial disposition of the results of governmentally supported research. Many universities acquired and took control of patent rights and established offices to promote their commercial exploitation. These changes in academic practice and organization were quickly accepted by most academic scientists and engineers; others were skeptical as to whether the university was taking on a function that would be detrimental to the traditional academic culture of disseminating knowledge through publication. Since active participation on the part of the faculty was voluntary; the level of controversy was relatively low.

Technology transfer is one of several ways that the U.S. conducts an industrial policy without officially having one (Etzkowitz, 1994a). The primary licensees of academic technology patents are small companies, that are generally located close to universities. These companies are more receptive to new ideas and have mechanisms available to 
attract and compensate academic scientists who are interested in seeing their ideas utilized. As Vannevar Bush, put it, "The purpose of issuing a patent is not to reward the inventor, but to enable the investment of venture capital, without which many inventions would die on the vine. The patent also enables small companies to carve out a corner for themselves in a large field, and to grow and prosper in the midst of large, powerful competitors" (Bush, 1970: 84). The crucial role of the federal government role in funding basic research that is carried out in universities, and in fashioning the patent policies that have encouraged the economically productive usage of this research by small firms, is the single most important way that government supports high technology innovation in the U.S.

Arising over the past century, the institutional mechanisms for handling academic patent rights have been generalized from a few universities such as MIT, where they originated, to the academic system as a whole (Etzkowitz and Webster, 1994). These practices represent a potentially fundamental modification of the traditional view of universities as institutions supported by governmental, ecclesiastical and lay patronage. The new arrangements open the possibility that universities will become, at least in part, financially selfsupporting institutions, entities obtaining revenues through licensing agreements and other financial arrangements for the industrial use of new knowledge discovered at the universities. At present, this possibility is little more than that but it certainly represents a novel idea in the history of universities, at least on the scale in which it is envisaged.

\section{NOTES}

1. The most direct and readily measurable consequences of the Bayh-Dole Act have been the royalties that have been earned by academic institutions that have licensed the inventions to which they have elected title. Taking the passage of the Bayh-Dole Act as a starting point, the National Science Board of the National Science Foundation, "University-Industry Research Relations" provides a comprehensive analysis of all aspects of university-industry relations as they entered the "Bayh-Dole" era. The authors report that they surveyed the top 36 recipients of federal funding. 25 responded and reported royalty income as follows: $1981 \$ 7.3$ million, $1982 \$ 9.2$ million.

The next year for which good quality data exist is 1986. In that year, the General Accounting Office carried out a study, "R\&D Funding: Foreign Sponsorship of U.S. University Research". (GAO/ RCED-88-89BR; Appendix 33). Although the schools were not identified, 112 institutions reported royalty income of: $\$ 30.3$ million.

Four studies were conducted in 1988 . The first was a comprehensive survey carried out by Marjorie Forster of the University of Maryland at Baltimore and reported at the May 1990 AUTM Conference on technology transfer performance assessment. 70 institutions, 63 U.S. and 7 Canadian, reported to this survey that they had received royalty income of $\$ 60.4$ million. Of the U.S. institutions, 25 allowed their royalty income to be individually reported, while the rest asked that it not be individually disclosed. One Canadian institution allowed its royalty income to be reported. Of the remaining $38 \mathrm{U}$.S. institutions, 17 reported that they had no licenses generating royalties and 21 reported royalty income on a confidential basis.

The second survey was carried out by John Preston Director of Technology Transfer at MIT. He queried 7 of the largest recipients of royalties and importantly included data for several universities that were not included in Forster's study. Total royalty income for the seven was $\$ 38.3$ million. The third study was by Terri Wiley of the Indiana Corporation for Science and Technology, as part of a study of technology transfer practices. individual figures are very similar to those in the 1988 AUTM survey, but one or two additional institutions were included. The fourth study was carried out by the law firm Pravel, Gambrel, Hewitt and Kettleberger. They surveyed 38 institutions and found total royalty income of $\$ 18.9$ million. Assuming that every institution surveyed by Marjorie Foster reported its royalty income, then the other studies allow a further 13 institutions to be added, giving, \$70.1 million in 1988 .

Two studies are available for 1989, 1990. The first is the second AUTM survey, carried out by Marjorie Forster and Steve Atkinson of Harvard Medical School and reported to the San Francisco 1992 Annual Meeting. This survey included data for 22 universities and hospitals for 1989, 1990 and 1991. For 1990, it included data for seven non-AUTM members who chose to respond to a questionnaire. The 1990 data included the $\$ 50$ million lump sum payment from Amgen to Memorial Sloan Kettering. For the consensus figure, this was not included. The second source was another GAO study "University Research - Controlling Inappropriate Access to Federally Funded Research Results", (GAO/RCED92-104) carried out at the request of Senator Ted Weiss' Subcommittee on Human Resources and Intergovernmental Relations of the Committee on Government Operations. This report included data for 31 institutions. The study combined the figures for the two years into a single total, $\$ 113.1$ million. For the purposes of this analysis, they were dissaggregated by assuming that $45 \%$ of the total 
pertained to 1989 and $55 \%$ to 1990 . This is in line with the estimated growth rate of $20-30 \%$ in royalties throughout the 1980's. Importantly, some of the institutions with high royalty incomes such as Michigan State and Wisconsin, who had not reported to AUTM had to report to GAO. An interesting part of this study is the differentiation between licenses and royalties derived from NSF and NIH funded technology and from all other funding sources. \$82.1 million out of the $\$ 113.1$ million was derived from NSF and NIH funded technology.

The result is a rather unsatisfactory figure for 1989 (\$89.2 million), covering only 53 institutions and barely exceeding the 1988 figure which covered 66 institutions. For 1990 (\$125.4 million), the data are rather better and cover 63 institutions. For 1991, 1992 and 1993, comprehensive surveys are available from AUTM.

2. Separate figures for RCT were not included in these earlier studies (RCT has reported to the 1991-1993 AUTM surveys.) While the distributed portion of the royalty proceeds will show up in the reported royalty income of the originating institutions, the retained portion will not. This portion should therefore be added to the individually reported figures. With the 1991 and on AUTM surveys, the opposite problem pertains - the distributed portion is double counted and must be subtracted from the total.

3. The largest single federal royalty earner is the AIDS test kit, accounting for almost half the total. It is also worth noting that the 1991 and 1992 AUTM data only includes $\mathrm{NIH}$, resulting in probably a $\$ 1$ million under count.

4. Several adjustments need to be made in the data. First, the income from the Cohen-Boyer patent is paid to Stanford, which subtracts a $15 \%$ management fee and pays half of the remainder $(42.5 \%$ of the payments) to the University of California. The UC component is therefore double reported and must be removed.

Second, one of the early, major royalty generators, City of Hope Hospital in Los Angeles, did not report to any of the surveys before the AUTM survey. City of Hope had carried out the genetic engineering of both insulin and human growth hormone for Genentech before Genentech had its own laboratories. We have obtained these data by personal communication and added them to the data.

5. The consensus of a workshop at the 1993 Annual Meeting of AUTM, which included representatives of many of the academic institutions with large royalty incomes, was that $2 \%$ was a good figure. Looking at some of the specific contributors to the total, the Cohen-Boyer patent is non-exclusively licensed for rates in the $1-1.5 \%$ range (and only applies to U.S. sales); the Columbia co-transformation patent is a production patent that is also non-exclusively licensed; the royalty rate on the Memorial SloanKettering G-CSF patent was bought down to $3 \%$ and only applies to sales over $\$ 350$ million per year; so this rate certainly appears reasonable.

6 . The average sales per employee of the S\&P 500 in 1992 was $\$ 169,000$ per employee. The consensus of a workshop at the 1993 Annual Meeting of AUTM was that the small high tech companies that are the primary licensees of academic technology have sales per employee of $\$ 125,000$. 137,800 jobs workers would be required to generate $\$ 17.2$ billion in product sales at $\$ 125,000$ in sales per employee. In the future, this figure could be more precisely defined by using database summaries of actual company data by industry.

\section{REFERENCES}

Bush, Vannevar

1970 Pieces of the Action. New York: Morrow

Etzkowitz, Henry

1990 "The Second Academic Revolution" In Susan Cozzens and Peter Healey (eds.) The Research System in Transition Amsterdam: Kluwer.

Etzkowitz, Henry

1993 "Enterprises from Science: The Origins of ScienceBased Regional Economic Development", Minerva 31 (Fall): 326-360.

Etzkowitz, Henry

1994a "Technology Centers and Industrial Policy: the Emergence of the Interventionist State in the USA" Science and Public Policy 21 (April): 79-87.

Etzkowitz, Henry

1994b "Knowledge As Property: The Massachussetts Institute of Technology and the Debate Over Academic Patent Policy" Minerva 32 (Winter): $383-421$.

Etzkowitz, Henry

1994c "Beyond the Frontier: The Convergence of Military and Civilian R\&D in the U.S." Science Studies 2/94: 5-22.

Etzkowitz, Henry

1995 "The Turn to Universities and SME's: The Emergence of the "Triple Helix" in Scandinavia" Technology Access Report. Vol 8. No. 11. (November): 10-11.

Etzkowitz, Henry and Andrew Webster

1994 "Science as Intellectual Property"., Pp. 480-505 in Handbook of Science and Technology Studies Sage: Beverly Hills.

Faulkner, Wendy and Jacqueline Senker

1995 Knowledge Frontiers: Public Sector Research and Industrial Innovation in Biotechnology, Engineering Ceramics, and Parallel Computing. Oxford: Oxford University Press.

Feller, Irwin

1990 "Universities as Engines of R\&D Based Economic Growth - They Think They Can" Research Policy. $19,335-48$.

Guston, David and Kenneth Kenniston

1994 The Fragile Contract. Cambridge: MIT Press.

Hofstadter, Richard and Wilson Smith

1962 American Higher Education: A Documentary 
History, Volume Two. Chicago: University of Chicago Press.

Jencks, Christopher and David Riesman

1968 The Academic Revolution. New York: Doubleday

Kloppenberg, Jack

1988 First the Seed: The Political Economy of Plant Biotechnology; 1492-2000 Cambridge: Cambridge University Press.

Kohler, Robert

1979 "Warren Weaver and the Rockefeller Foundation Program in Molecular Biology: A Case Study in the Management of Science" In Nathan Reingold (ed.) The Sciences in the American Context: New Perspectives. Washington DC: The Smithsonian Institution.

Latker, Norman

1977 patent counsel, Dept of Health, Education and Welfare, House subcommittee on Science, Research and technology, May 26 95th Congress, 1 st session. p.8.

National Science Board

1982 of the National Science Foundation, UniversityIndustry Research Relations Washington D.C. U.S. Government Printing Office

Office of Technology Assessment

1991 Federally Funded Research: Decisions for a
Decade. Washington D.C. U.S. Government Printing Office.

Office of Technology Assessment

1993 Pharmaceutical R\&D: Costs, Risks and Rewards. Washington D.C. U.S. Government Printing Office.

Owen, Larry

1994 "The Counterproductive Management of Science in the Second World War: Vannevar Bush and the Office of Scientific Research and Development" Business History Review. 68 (Winter): 515-576.

Pursell, Carroll

1979 "Science Agencies in World War II: The OSRD and Its Challengers" In Nathan Reingold ed. The Sciences in the American Context: New Perspectives. Washington DC: The Smithsonian Institution

Henry Etzkowitz

Science Policy Institute

State University of New York

Purchase, NY

Ashley J. Stevens

Community Technology Fund

Boston University, MA 